\title{
A Performance Evaluation of Environmental Education Regional Centers: Positioning of Roles and Reflections on Expertise Development
}

\author{
Yu-Long Chao \\ Center for General Education, National Formosa University, Yunlin 632301, Taiwan; chaoyulong@nfu.edu.tw
}

Received: 17 February 2020; Accepted: 20 March 2020; Published: 23 March 2020

\begin{abstract}
Emulating the practice of regional centers for expertise on education for sustainable development, a new type of environmental education (EE) centers with a multi-county jurisdiction was established in Taiwan. Reflections on the functional roles and EE expertise are crucial for these EE regional centers after implementing initiatives while trying to lead environmental educators. The operation team members of these centers and the practitioners and educators from EE institutions, facilities, and venues in Taiwan all participated in this investigation on the roles of these centers and evaluated their performance. Results show that at this initial stage of EE regional center development, the mixed views of center operation teams were averaged into a position close to the mean between a practice-orientated and a strategy-orientated methodology on a spectrum of the center roles. The evaluation results revealed a certain insufficiency in the experiences and expertise in EE of some EE regional centers. As these centers are endowed with a central status by policy to promote and guide regional EE, they need to learn from local grass-root environmental educators as well as other EE regional center personnel to substantiate their expertise, which could be achieved through practical experiences and co-research with local environmental educators.
\end{abstract}

Keywords: environmental education center; role positioning; expertise development; evaluation; university

\section{Introduction}

Year 2011 saw a significant milestone in the development of Taiwan's environmental education (EE), as the Environmental Education Act was enacted to engage more citizens in acquiring knowledge about, forming the ethical values of, and taking actions for the environment that are fundamental, in the shifting toward sustainable development. The Act prescribes the certification of educators, institutions, facilities, and venues in EE, among which the environmental education institutions are established to train persons to be certified as environmental education personnel; the environmental education facilities and venues are to provide venues where a variety of EE programs for the public take place; and the environmental education personnel are to be responsible for the EE practices of their organizations including schools, governmental departments, state-owned enterprises, and the certified EE institutions and facilities/venues. By the end of 2019, there were 13,030 certified EE personnel, 30 EE institutions, and $197 \mathrm{EE}$ facilities/venues across Taiwan.

There have been centers with titles including the terms either "environmental education" or "nature education" across the country since 1988 [1]. These range from the Environmental Education Centers established by the Ministry of Education in normal universities or universities of education and missioned to provide EE workshops for school teachers and organize campus EE activities; the Nature Education Centers of the Bureau of Forestry that provide nature-based EE programs to the public; and the Environmental Education Centers founded by city or county governments, most of 
which function as exhibition venues of EE media for citizens. As environmental awareness increases in Taiwan society [2] and the EE Act creates momentum for the implementation of EE initiatives in schools and organizations, numerous EE practitioners and environmental educators have taken part in education in, about, and for the environment in different places, with multiple approaches.

Inspired by the Regional Centers for Expertise (RCE) on education for sustainable development (ESD) that the United Nations University launched [3], Taiwan's Environmental Protection Administration (EPA) commenced establishing Environmental Education Regional Centers in southern, central, northern, and eastern regions in 2014. It is valuable to have regional centers for both educators and learners in different regions of the country available for contact about EE resources and information and, as well, for Taiwan's EPA to promote EE policies more efficiently. The institutional basis of these EE regional centers is a three-year (2014-2016) project funded by Taiwan's EPA. A subsequent project for 2017-2019 was implemented, dividing the country into more regions, thereby increasing the number of EE regional centers from four to six. Consistent with the scheme of RCE in which universities play a role of a leader in ESD in the regions, all these EE regional centers are located in and operated by a university in each region covering several metropolises and counties.

Taiwan's EPA assigned the EE regional centers five major tasks, which are modeled after the project EECapacity of the U.S. Environmental Protection Agency [4]. These tasks are operationalized in the EE regional center establishment project as follows [5]:

1. Academy leadership: absorbing international advances that then go through domestic conversions to develop expert EE strategies;

2. Capacity building: increasing the professional competencies, attitude, and techniques of environmental educators to make them models;

3. Technological support: developing technology-aided teaching methods that respond to environmental changes and technology advances;

4. Research and evaluation: devising operation systems for EE institutions, mechanisms of market needs for EE personnel, integrated management tools and performance evaluation systems for EE regional centers; and

5. Dissemination partnerships: networking with local partners and forming social communities on EE to promote regional EE.

The completion of the first phase (2014-2016) of the EE regional center establishment project symbolizes a first step taken toward conducting the practices of EE with the assistance of and guidance from EE centers at a regional level in Taiwan. It could be too early to examine what impacts this step brought about, but it is necessary to assess how well this step has been taken at the present stage. Individuals of organizations involved in these practices such as EE facilities, venues, and institutions, are eligible to be informants about the performance of the EE regional centers over the three years. An evaluation based on ratings given by these stakeholders should reflect the strengths and weaknesses of EE regional centers in performing these five mandated tasks. On the side of the operation teams of EE regional centers, besides that, they can also appraise the performance of their peer centers and therefore find it critical to jointly address certain important issues of the roles of EE regional centers. These issues concern whether an EE regional center should be practice- or strategy-oriented, and therefore determine what subjects it should proactively and directly reach. It is in fact linked to the different geographic levels at which EE centers are situated, that in turn differentiate the relative importance among roles as well as tasks to some extent. That is, conventional EE centers in many localities and communities and these new types of EE centers established in regions covering a number of metropolises and counties differ in roles and major tasks; one could aim at conducting EE practices to the public while the other could focus on providing guidance and resources to environmental educators.

On-site observation, however, reveals that the staffs of EE regional center operation teams seem to multitask a lot in providing the public with various programs and initiatives as well as in giving EE organizations and environmental educators guidance in strategies and expertise. Yanniris [6] 
commented that research on EE centers was limited in terms of qualitative approaches and scarcely addressed participants' perceptions of the functions and contribution of the centers. In order to fill this deficiency in research, this study, based on the experiences and views of the members of EE regional center operation teams, attempts to clarify the appropriate role position of EE regional centers at the present stage in a context of Taiwan's EE policies. Meanwhile, it evaluates the performance of EE regional centers in fulfilling these roles with the samples of the practitioners and environmental educators from regional EE institutions, facilities, and venues. Self-reflection is a basis of evaluation for many RCEs [7], so reflections on the leadership in EE might be salient in the evaluation results of this study, most notably the concerns about what should be and how to increase the expertise of the members of EE regional center operation teams. Other results of this study should make policy recommendations with respect to effective and benign development of EE regional centers on one hand and contribute to the barren field of research on theories of EE organization on the other.

According to the above five mandated tasks, the regional EE centers in this study refer to the EE centers, each of which is planned to be established in one of a few large regions into which a country is divided, i.e., at a geographic level higher than city and county. These centers' titles might not necessarily include the word "regional" in the cases of other countries and they could be commissioned to perform more tasks than the typical task of providing EE to the general public. For example, Taiwan's regional EE centers are practically offices in the buildings in universities and are hence not situated in a natural environment where most EE initiatives and programs for the general public take place. These non-conventional EE centers have drawn our attention to probe into the following salient questions to be addressed in this study:

1. How are the performances of Taiwan's regional EE centers in undertaking the five major mandated tasks?

2. What is the perceived position between practice- and strategy-oriented roles that the regional EE centers should play?

3. Are the operation teams of the regional EE centers considered adequate in the experience and expertise of leading the development of EE in their respective regions?

\section{Literature Review}

\subsection{Regional EE Center Studies}

Though EE centers or nature centers might have been the source of learners, programs and environmental educators that have been investigated in studies, as Medir, Heras and Geli [8] noted, the centers themselves and their internal operation mechanisms are rarely the focus of study. Examples of sporadic studies focusing on EE/nature centers include investigations on such themes as the service effectiveness of nature centers [9], the functions of Korean EE centers [10], community support of nature centers, and their views on the values of nature centers [11,12]; the influence of Greek EE centers on local communities [13]; Australian school principals' perceptions of the roles of outdoor and EE centers [14]; views of directors of U.S. EE centers on a successful EE center [15]; along with earlier works that examined the goals of and summarized successful guidelines for these centers in the U.S. [16-18]. Despite some overlap in services and functions, the regional EE centers, to a certain extent, differ from these conventional centers that have natural settings and facilities, mostly at a local or community level. This difference might be of particular importance in the sense that an EE center at a higher geographic level shifts the focus of EE center research from practical issues to strategic ones such as capacity building of educators, regional EE networking, EE expertise, and organization performance. The establishment of national and regional centers for EE was advocated in the conference of the North American Association for Environmental Education (NAAEE) as early as in 1983 [19]. Similarly, Viloria [20] suggested the necessity and strategy of a network of "regional centers of environmental education and training" for developing countries. Indeed, an EE needs assessment of 
teachers, and a regional center is highly ranked and expected by teachers to provide useful resources and information [21].

With the above specification in center attributes (e.g., featuring strategic functions or serving as a resource hub for educators) and geographical level (i.e., regional), even scarcer relevant studies become screened out. These studies are a content analysis of the guiding documents of $23 \mathrm{EE}$ centers in Spain [8] and an argument about the "change agent" role of NGO EE centers in Indonesia [22]. Studies in regional EE centers are just beginning in Taiwan, too. So far, there are four studies focusing on its regional EE centers, covering the following topics: a comparison on the systems, roles, and practices of regional EE centers in Taiwan and Korea [23]; roles and approaches of a university, as a regional EE center, participating in promoting regional EE with local governments [24]; the collaboration with partner organizations of regional EE centers [25]; and the operation and evaluation of a regional EE center [26]. From a perspective of regional EE development, the insufficiency of research in regional EE centers points to an area that needs addressing.

\subsection{Roles of Regional EE Centers}

Traditionally, the functions or roles of any EE center, regardless of its geographic level, can be categorized into the three facets as Wilson and Martin [17] summarized, providing environmental information, providing opportunities for EE through programs and facilities, and conducting EE research and collaborative works. Providing EE opportunities through programs has long been the major function of EE centers [15,17], which is evident in a recent national survey of Browning et al. [12], finding that for nature centers, the most-valued function is the environmental connection formed in nature-based learning that increases environmental awareness and behavior. Regrettably, similar studies that empirically analyze other additional roles or services of these centers are rare, just as Browning et al. [12] highlighted that the broader values of nature centers are yet to be studied. There are still some informative viewpoints about the potential roles of a regional EE center. To begin with, an EE center can also be a regional resource and professional training center for EE [27], implying that the functional roles of EE centers can evolve from a typical program provider of EE as a result of the geographical level at which they are established or their host/operating institutions. A regional EE center might compare to a state-level EE organization, which Smaldone and Dey [28] considered functioning as "a hub for EE resources" and attempt to collaborate with the public, NGOs, and governmental organizations. In cases where the EE center is hosted by a university, like the operation of regional centers for expertise (RCE) on education for sustainable development (ESD), its roles or functions are broadened to cover an engine for mobilizing diverse stakeholders for ESD, a coordinator and an intermediary support structure for local-regional ESD activities and related initiatives in the region, and a facilitator of social learning [29]. Viloria [20] suggested that university-based EE centers should have five inter-related functions: research and information dissemination, training, advisory services, monitoring, and conducting pilot or demonstration projects. The Tennessee Valley Authority set these functions for similar centers: teacher training, program development, regional outreach services, and research [30]. A recent case is the regional center for EE established in Northern Kentucky University that is commissioned to coordinate environmental education across the Northern Kentucky region by professional development for educators, P-12 outreach, partnerships, and community environmental stewardship projects and events [31]. Liang's [24] study on the Eastern EE regional center in Taiwan argued that the major tasks of EE regional centers are social community development, professional resource provision, human resource cultivation, and the creation of a platform for information exchange. Additionally, in eastern Asia, though not university-based, with a national-regional-local hierarchy of EE centers set in Korean's legal context, Cha et al. [10] suggested that the regional EE center seek balance among the three functions of education/training, research development, and network construction.

Since EE centers are important in both non-formal and formal education systems during lifelong learning [14,32-34] and more flexible than formal education institutions with the ability to adapt to changing educational challenges [33], in the long term, they are believed by some researchers to have 
more extensive impact on society. Yanniris [6] described that they act as catalysts for the development and delivery of EE in a society. Applying Rogers' [35] concept of change agent that facilitates the resource flow from a resource system to a client system, Nomura et al. [22] proposed a fourth role in addition to Wilson and Martin's [17] three conventional ones: a translational role as a change agent between local educators (client system) and national and international educational resources (resource system).

EE centers, regardless of their geographic levels, inevitably play an influential part in putting into practice the sustainable development goals (SDGs) advocated by United Nations [36]. In the cases where the EE centers are operated by universities, the centers should inherit the role of host universities as a change agent for sustainability [37,38]. Stephens et al. [37] argued that higher education institutions could fulfill that role at levels from strategic to operational ones; the strategic level aims at higher-level activities of leaders while the operational level focuses on project building and implementation. These levels could be suggestive for the inquiry of what Taiwan's EE regional centers are doing now and should do, in the future. Besides, as Havea and Mohanty [39] emphasize that EE professionals are essential in the success of sustainable development and the professional development in education can assist in the realization of not only SDG 4 (quality education) but also other SDGs, whether the operation team members of EE regional centers have necessary expertise in EE or ESD could be a major concern of much relevance to the fulfillment of the centers' ideal roles.

Different roles of EE centers involve different target subjects and organizations. As a developer and provider of EE programs, an EE center makes contacts largely with schools and the general public, while as a capacity builder and an agent it interacts with practitioners and environmental educators in communities and EE organizations. Modern EE centers could play multiple roles, some of which are given prominence as a result of EE policies and/or their geographic levels and therefore present different orientations. Systematic studies based on empirical investigations of a cluster of EE centers are needed, which are rare in the literature so far.

\subsection{Evaluation of EE Regional Centers}

Empirical evaluation studies on the performance of EE centers are also limited in the literature. Examples include a qualitative survey on the evaluation strategies of Czech EE centers [40], the educational and managerial performance of NGO EE centers in Indonesia [22], and assessments and evaluation of RCE on ESD [41,42]. The findings of these studies and principles suggested by other discursive works are illuminating for the preliminary trial of this study to evaluate Taiwan's EE regional centers. It has been advocated that the EE centers be evaluated by objective outsiders $[40,43]$ so that their documented experiences would be beneficial to a larger audience [43]. These participatory evaluations with their participants appraising the performance would be advantageous for the RCE in not only the reflection on their work but better partner understanding of how they are being connected in the network as well [44]. Nevertheless, it must be noted that some external evaluators could have limited expertise in EE [40] and some of these outside experts could make evaluations that are destructive and misrepresentative of the essence of the centers [44]. In case that an overall picture of the center is incomplete and biased by internal evaluators, Dlouhá et al. [42] considered both internal and external evaluation as being necessary for RCE.

O'Donoghue and Fadeeva [7] summarized three evaluation approaches of RCE: (1) Appreciative enquiry that documents and analyzes the positive experiences of RCE members in accomplishing missions; (2) constitutive evaluation that focuses on the core components and functions of RCE; and (3) strategic evaluation which involves assessment of contextual factors that influence the practices of RCEs and the impacts of their activities. In reference to the initial stage of the development of Taiwan's EE regional centers, the approach of constitutive evaluation might be of considerable relevance to the present needs to assess how well the assigned tasks of these centers are undertaken. Both EE regional center operation team members and external practitioners and environmental educators from EE facilities/venues and institutions in the region who participate in the activities of EE regional centers are eligible evaluators. 


\section{Methods}

\subsection{Participants}

In the inquiry of the role positions of Taiwan's regional EE centers and the evaluation of their performances, those who are directly involved in the practices of the centers deserve to be the subjects of this study, being composed of two groups of persons: those who operate the centers and those who receive the services of the centers. The former was a sample of the members of operation teams of the four EE regional centers, consisting of project hosts, coordinators, managers, assistants, and other key professors involved in each center: 18 respondents; the latter was comprised of the practitioners, environmental educators, staff, and managers of EE facilities and venues (78 individuals) as well as the staff and directors of EE institutions (22 individuals): 100 respondents (Table 1). These two groups of individuals were approached in two respective surveys. As the numbers of EE institutions, facilities and venues among regions vary greatly in the first place and the willingness of individuals contacted to participate in the survey could not be guaranteed, the numbers of respondents evaluating the EE regional centers in the four regions respectively are inequivalent. The respondents in EE regional center operation teams evaluated all EE regional centers including the one they were affiliated to; hence, no number of evaluators of each EE regional center is provided.

Table 1. The number of respondents.

\begin{tabular}{|c|c|c|c|c|c|c|}
\hline \multirow{2}{*}{ Group } & \multirow{2}{*}{ Organization } & \multirow{2}{*}{ Sum } & \multicolumn{4}{|c|}{$\begin{array}{c}\text { Number of Respondents as Evaluators in the Evaluation } \\
\text { on Each EE Regional Center }\end{array}$} \\
\hline & & & $\begin{array}{l}\text { Northern } \\
\text { Center }\end{array}$ & $\begin{array}{l}\text { Central } \\
\text { Center }\end{array}$ & $\begin{array}{l}\text { Southern } \\
\text { Center }\end{array}$ & $\begin{array}{l}\text { Eastern } \\
\text { Center }\end{array}$ \\
\hline \multirow{2}{*}{1} & EE facilities/venues & 78 & 18 & 28 & 20 & 12 \\
\hline & EE institutions & 22 & 6 & 3 & 11 & 2 \\
\hline 2 & $\begin{array}{l}\text { EE regional center } \\
\text { operation teams }\end{array}$ & 18 & & & & \\
\hline
\end{tabular}

\subsection{Sampling}

Email invitations for the survey on EE regional center evaluation were sent to the above two groups of persons during April-July, 2017. It was the first phase (2014-2016) of the EE regional establishment project of Taiwan's EPA that was investigated in this study. During the phase, there were totally 4 regional EE centers, $21 \mathrm{EE}$ institutions, and $107 \mathrm{EE}$ facilities/venues throughout Taiwan. Respondents from the operation teams of the four EE regional centers and EE institutions could be considered as purposive samples since the members of the teams and institutions were small in number (on average, approximately 6 for each team and 3 for each institution) and the emails were sent specifically to each member, whose email addresses can be found on the website of their center or institution. The response rates were estimated as $75 \%$ for the teams and $52 \%$ for institutions. To invite environmental educators, staff and managers of EE facilities/venues, we sent emails to the representative email addresses of the facilities/venues publicized on the website of EE Information System hosted by Taiwan's EPA. Recipients of those emails were asked to forward the survey to the staff and managers liable for the survey. Each EE facility/venue generally has around two environmental educators/staff and one manager, on average. It is estimated that $24 \%$ of these persons of all facilities/venues could have responded to the survey.

\subsection{Instruments}

Two online questionnaires were designed for two groups of participants respectively: members of EE regional center operation teams and those of EE institutions and facilities/venues. The two questionnaires focused on different aspects of the EE regional center. The one for EE regional center operation team members collected data on the members' views about the roles and positioning of EE regional centers as well as a cross evaluation (every member evaluates his or her center and 
other centers) on the performances of the four EE regional centers; the other for the members of EE institutions and facilities/venues asked these members to give ratings on the performances of the EE regional centers in their regions and investigated their needs for EE capacity building in different topics. The categories of responses to the items of questionnaires conformed to the role orientations summarized from the literature, the five major tasks specified in the policies of Taiwan's EPA, and the eight thematic areas of EE outlined in regulations.

\subsubsection{The Questionnaire for the Operation Team Members of EE Regional Centers (Appendix A)}

- A cross evaluation on the performances of each of all four EE regional centers in each of the five major tasks

- Perceived allocation of the percentages of the five major tasks, an item asking respondents to allocate the percentages to each of the tasks according to their perceived importance of the task

- Positioning between practice-oriented and strategy-oriented roles, indicated by one item on a 7-point scale ranging from 1 (practice-oriented) to 7 (strategy-oriented)

- Main categories of subjects that EE regional centers should proactively and directly reach, with one item providing five categories from which more than one can be chosen: Corporate, schools, NGOs, EE personnel, and general public. It is followed by nine items presenting the possible reasons for the choices and measuring the extent to which respondents agreed with the reasons using a 5-point scale ranging from 1 (strongly disagree) to 5 (strongly agree)

- The attitude toward EE regional centers' fostering the industrialization of EE, with one item using a 5-point scale ranging from 1 (strongly disagree) to 5 (strongly agree)

- Views on the legal status of EE regional centers, an item with two categories: established by the Taiwan EPA projects or established by EE Act

\subsubsection{The Questionnaire for Members of EE Institutions and Facilities/Venues (Appendix B)}

- Evaluation on the performances of the EE regional center in the respondent's region in each of the five major tasks along with the associated indicators

- The topics in which one has need for capacity building or is interested

- The thematic areas of expertise in which one has need for capacity building or is interested

The evaluation section of the above questionnaires consisted of five items corresponding to the five major tasks of the EE regional center. These items of performance evaluation in both questionnaires were devised according to the official document of Taiwan's EPA project of EE regional center establishment using a 10-point scale. For example, with respect to one of the five major tasks, say academy leadership, respondents were asked to rate the performance of one EE regional center on the task with ratings from 1 (Lowest) to 10 (Highest).

\subsection{Data Analysis}

Descriptive statistics and charts were used in presenting the views of respondents concerning the roles of EE regional centers and their evaluation on the performance of these centers. In analyzing the results of evaluation on EE regional center performance, the differences between the mean scores rated by members of EE regional center operation teams and those rated by members of EE institutions and facilities/venues were tested with t-tests of independent samples. With ANOVA, the differences among the four EE regional centers in mean total scores of the five major tasks were tested. The differences among these centers in the five mean scores of the five major tasks were tested with multivariate analysis of variance (MANOVA), with the Games-Howell adjustment being employed for post hoc tests. The adjustment is suitable for data with unequal group sizes, heterogeneous variance, and non-normality [45]. For the data with small samples of EE regional center operation team members, Mann-Whitney $U$ tests were performed to detect the differences when the data did not approximate a normal distribution. 


\section{Results}

\subsection{Demographic and Professional Profile of Respondents}

Since the EE regional centers are operated exclusively by academic units in universities, the 18 respondents from the four EE regional center operation teams were composed of the academics and assistants in universities, who had at least a master's degree. They were aged around 30 or 40 years old and above, and 11 (61.1\%) of them were male, with more than half $(61.1 \%)$ having held a certificate of EE personnel for three to five years. The other group of 100 respondents who were members of EE institutions, facilities and venues were approximately gender-balanced; with the distribution of education levels being master's degree $49.0 \%$, bachelor's degree $34.0 \%$, doctorate $9.0 \%$, and under bachelor $8.0 \%$. As the EE practitioners or environmental educators in the field, most of them $(77.0 \%)$ had a certificate of EE personnel and $57.0 \%$ of them had received it within the last three years. They served as administration staff $(42.0 \%)$, middle managers $(31.0 \%)$, senior managers $(11.0 \%)$, and EE teachers $(10.0 \%)$. Table 2 summarizes the demographics of these two groups of respondents.

Table 2. Demographics of the two groups of respondents.

\begin{tabular}{|c|c|c|}
\hline Demographics & $\begin{array}{l}\text { Members of the Four EE Regional Center } \\
\text { Operation Teams }(\mathrm{N}=18)\end{array}$ & $\begin{array}{c}\text { Members of EE Facilities, Venues, } \\
\text { and Institutions }(\mathbf{N}=100)\end{array}$ \\
\hline Age & Mean $=37.6, \mathrm{SD}=9.5$ & Mean $=37.6, \mathrm{SD}=10.0$ \\
\hline Gender & $\begin{array}{l}\text { Female: } 38.9 \% \\
\text { Male: } 61.1 \%\end{array}$ & $\begin{array}{l}\text { Female: } 52.0 \% \\
\text { Male: } 48.0 \%\end{array}$ \\
\hline Education & $\begin{array}{c}\text { Master: } 38.9 \% \\
\text { Doctorate: } 61.1 \%\end{array}$ & $\begin{array}{c}\text { Under bachelor: } 8.0 \% \\
\text { Bachelor: } 34.0 \% \\
\text { Master: } 49.0 \% \\
\text { Doctorate: } 9.0 \%\end{array}$ \\
\hline Position & $\begin{array}{c}\text { Project hosts/coordinators/managers: } 44.4 \% \\
\text { Assistants: } 55.6 \%\end{array}$ & $\begin{array}{c}\text { Senior managers: } 11.0 \% \\
\text { Middle managers: } 31.0 \% \\
\text { Administration staff: } 42.0 \% \\
\text { EE teachers: } 10 \%\end{array}$ \\
\hline $\begin{array}{l}\text { EE personnel } \\
\text { certification }\end{array}$ & $\begin{array}{l}\text { No certification: } 38.9 \% \\
\text { Certified: } 61.1 \% \text { (3-5 years) }\end{array}$ & $\begin{array}{c}\text { No certification: } 23.0 \% \\
\text { Certified: } 57.0 \% \text { (1-3 years) } \\
20.0 \% \text { ( } 3-5 \text { years) }\end{array}$ \\
\hline
\end{tabular}

\subsection{Role Positioning}

\subsubsection{Perceived Relative Importance of the Five Major Tasks}

Respondents from EE regional center operation teams gave their allocation of the percentages in which they thought EE regional centers should invest their efforts and resources in the five major tasks. Table 3 presents the mean of varying proportions respondents gave to each task. The task of dissemination partnerships had the largest mean proportion $(23.60 \%)$, capacity building, the second (22.21\%) and academy leadership, the third (20.01\%). The values of standard deviation reflected an agreement among the respondents on the importance of capacity building and relatively divergent views on that of research and evaluation.

Table 3. Perceived relative importance of the five major tasks.

\begin{tabular}{ccc}
\hline Task & Mean (\%) & Standard Deviation (\%) \\
\hline Academy leadership & 20.01 & 6.25 \\
Capacity building & 22.21 & 3.61 \\
Technological support & 16.84 & 4.84 \\
Research and evaluation & 17.34 & 7.54 \\
Dissemination partnerships & 23.60 & 5.43 \\
\hline
\end{tabular}




\subsubsection{Positioning between Practice-Oriented and Strategy-Oriented Roles}

The roles and functions of conventional and regional EE centers addressed in the above literature might be reduced to two orientations: practice-oriented and strategy-oriented (Figure 1). A practice-oriented EE regional center places emphasis on the ideal of popularization of EE and realizing actions in EE, specifies more types of organizations and populations as major targets, and provides proactive and direct services or programs/initiatives to these targets, although requiring more manpower, budget, and other resources. Relatively, a strategy-oriented EE regional center underscores the ideas, methods, and system operations of EE and specifies fewer types of organizations and populations as major targets to provide them with proactive and direct services (guidance/capacity building). It passively accepts inquiries from, participates in or provides indirect services to other types of organizations and populations on demand, so might require less resources. On a 7-point scale with 1 denoting the practice-oriented role, 7 the strategy-oriented role and 4 the middle point, the respondents gave a mean of 3.78 with a considerable standard deviation of 1.99 . The mixed inclinations of these are interesting and thought-provoking as well.

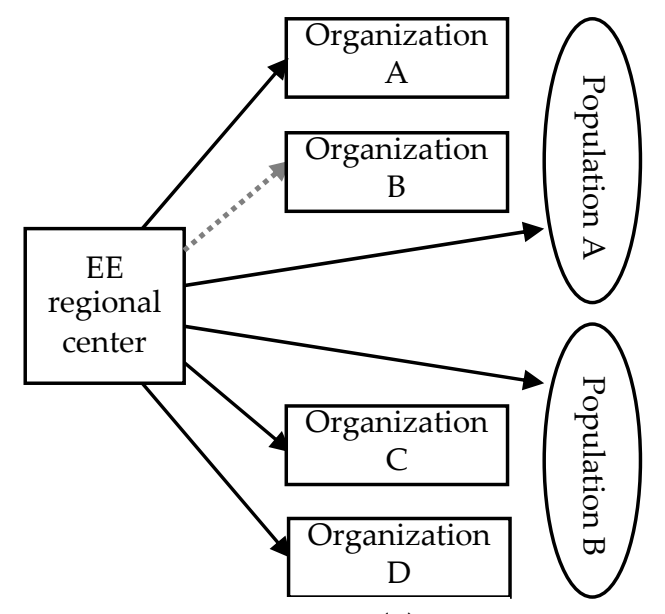

(a)

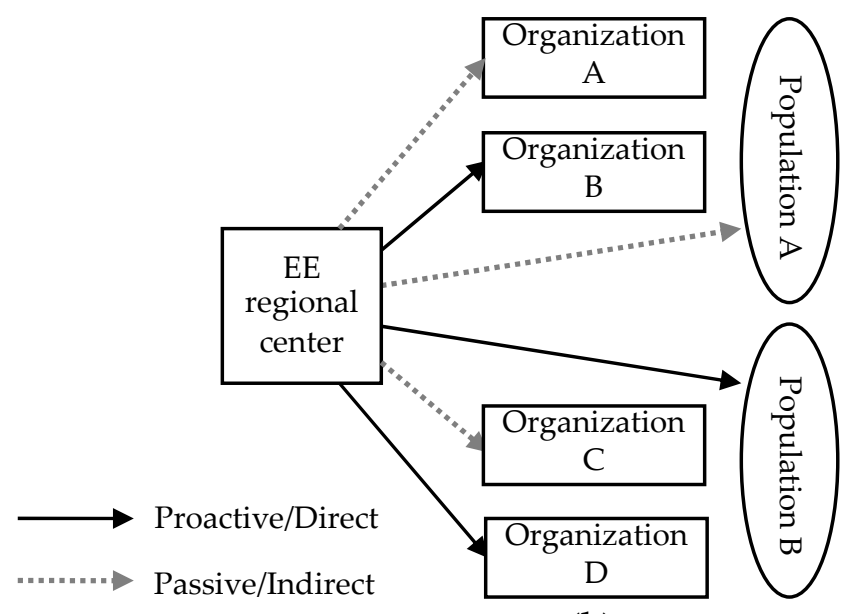

(b)

Figure 1. Practice-oriented (a) and strategy-oriented (b) EE regional centers.

\subsubsection{The Categories of Subjects to be Reached}

Taking account of the legal context of EE in Taiwan, we specified a set of categories of organizations and populations that the EE regional centers could reach. Figure 2 depicts this set of subjects consisting of EE facilities/venues, EE institutions, corporate, schools, NGOs, EE personnel, and general public. Respondents from EE regional center operation teams were asked to indicate, from the diagram, the subject categories that they thought the EE regional centers should proactively and directly reach. Except for EE facilities/venues and institutions, which are provided in the EE Act and inherently the important organizations that EE regional centers should work with, corporate and NGOs received the largest share of total votes (both with $28.0 \%$ ), followed by EE personnel $(21.0 \%)$, schools $(16.0 \%)$, and the general public receiving the fewest $(11.0 \%)$.

Table 4 presents the extents of approval of respondents from EE regional center operation teams regarding the nine given possible reasons for reaching or not reaching those subjects. On a 5-point scale, the eighth reason obtains the highest mean of approval (4.33), stating that the EE regional centers should proactively work with NGOs as they are important promoters in non-formal EE. The second highest mean (4.11) is found for the second reason that the EE regional centers and the organizations in the system of Ministry of Education need a division of labor in EE work, and schools are hence, not a subject to be directly reached. A reason with approximately high mean (4.06) for reaching as more categories of subjects as possible, is that it is what an EE regional center is supposed to do. There are two reasons with significantly low means of approval: 2.17 and 2.44. The lowest one is that the EE 
regional centers should avoid directly reaching corporate bodies because of their profit orientation; the other concerns the incompatibility between the controversies of NGOs and the nature of education and it therefore excludes NGOs from the subjects to be directly reached.

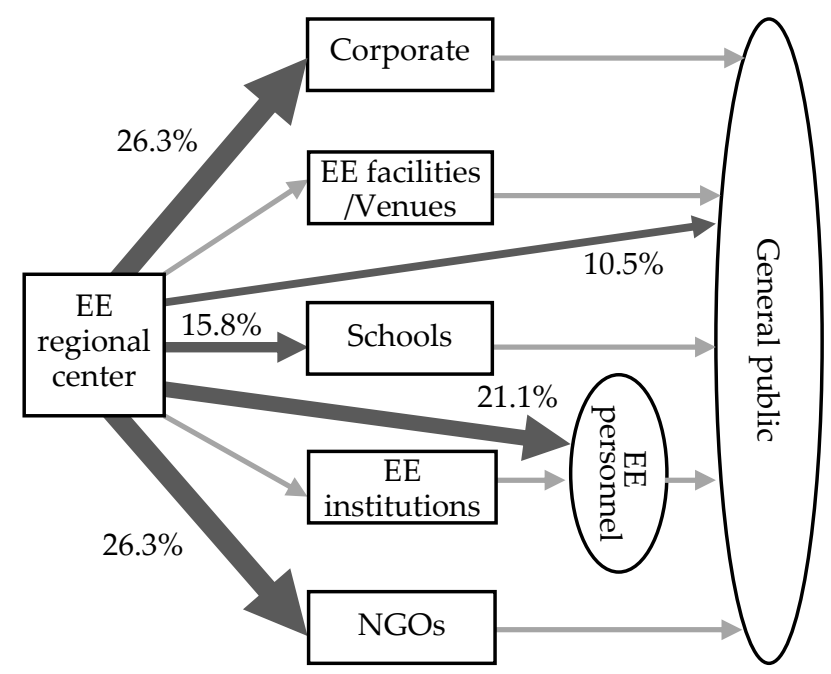

Figure 2. The categories of subjects that an EE regional center should reach.

Table 4. The reasons for designating the main categories of subjects to be reached.

\begin{tabular}{|c|c|c|}
\hline Reasons & Mean & $\begin{array}{l}\text { Standard } \\
\text { Deviation }\end{array}$ \\
\hline $\begin{array}{l}\text { An EE regional center is supposed to proactively and directly provide programs and } \\
\text { services to various subjects as best it can. }\end{array}$ & 4.06 & 0.73 \\
\hline $\begin{array}{l}\text { As schools at all levels are numerous, they should be provided with services by the } \\
\text { organizations in the system of Ministry of Education. The EE regional centers and } \\
\text { those organizations should work for EE in cooperation with a division of labor. }\end{array}$ & 4.11 & 0.76 \\
\hline $\begin{array}{l}\text { The role position of EE regional centers would not be different from that of the } \\
\text { numerous EE facilities/venues if they invested more effort and resources in providing } \\
\text { EE proactively and directly to the general public. }\end{array}$ & 3.94 & 1.11 \\
\hline $\begin{array}{l}\text { Having substantial practical experiences in proactively and directly providing } \\
\text { programs and services to the general public and schools is a prerequisite for the } \\
\text { expertise of an EE regional center. }\end{array}$ & 3.72 & 1.02 \\
\hline $\begin{array}{l}\text { The EE institutions are statutory institutions for EE personnel training; the function of } \\
\text { EE regional centers would overlap that of EE institutions if EE regional centers } \\
\text { proactively and directly provided capacity building/training programs. }\end{array}$ & 3.61 & 1.24 \\
\hline $\begin{array}{l}\text { Seeking corporate groups to invest resources or participate in the promotion of EE is } \\
\text { one of the important and major jobs of EE regional centers. }\end{array}$ & 3.72 & 1.07 \\
\hline $\begin{array}{l}\text { Corporate groups are profit-oriented so one should refrain from too many proactive } \\
\text { and direct interactions with corporations in promoting educational work. }\end{array}$ & 2.17 & 1.15 \\
\hline $\begin{array}{l}\text { NGOs are important promoters in non-formal EE so the EE regional centers should } \\
\text { proactively work with them. }\end{array}$ & 4.33 & 0.77 \\
\hline $\begin{array}{l}\text { The issues about which NGOs are concerned involve controversies of environmental } \\
\text { policies and are hence not compatible with the educational nature of EE regional } \\
\text { centers. They are not in the categories of organizations that must be reached. }\end{array}$ & 2.44 & 1.42 \\
\hline
\end{tabular}

\subsubsection{The Attitude toward the Industrialization of EE}

On average, the members of EE regional center operation teams hold a positive attitude toward the statement "Fostering the industrialization of EE in the region is one of the major tasks in which 
future EE regional centers should place their efforts," as indicated by the mean 3.94 (standard deviation 1.11) on a 5-point scale of the degree of approval.

\subsubsection{Views on the Legal Status of EE Regional Centers}

More than half (55.56\%) of the members of EE regional center operation teams chose to maintain the current legal status as an organization established by Taiwan's EPA working project; $33.33 \%$ of them preferred a higher status as a center that is prescribed in the EE Act. Others thought it depended on the level of environmental literacy of citizens or that the Act should only set the procedure of establishing any EE organization.

\subsection{Performance Evaluation}

\subsubsection{Total Scores of the Five Major Tasks}

Respondents rated each of the five major tasks of EE regional centers on a 10-point scale, summing up to a maximum total score of 50 for an EE regional center. The mean total scores that the four centers obtained are summarized in Table 5. For all centers, the mean scores rated by members of EE institutions and facilities/venues were lower than those rated by members of EE regional center operation teams; in particular, EE regional centers $C$ and A with statistically significant differences of means of 11.66 and 5.15, respectively. Results of ANOVA demonstrated no significant difference among the four EE regional centers in the mean total scores rated by members of EE regional center operation teams but showed significant difference between EE regional centers $\mathrm{A}$ and $\mathrm{C}$ in those rated by members of EE institutions and facilities/venues as well as in those rated by all respondents.

Table 5. Means of total scores of the five major tasks of EE regional centers.

\begin{tabular}{ccccc}
\hline $\begin{array}{c}\text { EE Regional } \\
\text { Centers }\end{array}$ & $\begin{array}{c}\text { Rated by Members of EE } \\
\text { Regional Center } \\
\text { Operation Teams (X) }\end{array}$ & $\begin{array}{c}\text { Rated by Members of } \\
\text { EE Institutions and } \\
\text { Facilities/Venues (Y) }\end{array}$ & $\begin{array}{c}\text { Differences of } \\
\text { Means (X-Y) }\end{array}$ & $\begin{array}{c}\text { Rated by All } \\
\text { Respondents }\end{array}$ \\
\hline A & $41.28(5.33)$ & $36.13^{\mathrm{a}}(5.46)$ & $5.15^{* *}$ & $38.33^{\mathrm{b}}(5.93)$ \\
B & $38.17(5.60)$ & $35.03(9.33)$ & 3.13 & $36.18(8.24)$ \\
C & $39.28(5.74)$ & $27.61^{\mathrm{a}}(13.02)$ & $11.66^{* *}$ & $31.90^{\mathrm{b}}(12.24)$ \\
D & $37.72(6.21)$ & $36.07(8.55)$ & 1.65 & $37.00(7.25)$ \\
\hline
\end{tabular}

${ }^{* *} p<0.01$; Numbers in parentheses are standard deviations. ${ }^{a}$ A statistically significant difference was detected between centers $\mathrm{A}$ and $\mathrm{C}$ in the post hoc test of the ANOVA for the four centers in the means of total scores rated by members of EE institutions and facilities/venues. ${ }^{\mathrm{b}} \mathrm{A}$ statistically significant difference was detected between centers $\mathrm{A}$ and $\mathrm{C}$ in the post hoc test of the ANOVA for the four centers in the means of total scores rated by all respondents.

\subsubsection{Scores of EE Regional Centers by Tasks}

Table 6 shows the mean scores of each of the five major tasks, into which the above total scores are broken down. These scores were also rated by two groups of respondents: members of the EE regional center operation teams (Group I) and members of EE institutions, facilities and venues (Group II). The scores rated by the former group ranged from 6.89 to 8.78 while those rated by the latter group were of values between 5.32 and 7.79. Again, almost all scores rated by the latter group of respondents were lower than the former group, with results of independent sample t-tests (the column of "Differences of means" in Table 6) showing that significant score differences between the two groups occurred in some tasks of centers A and B and all tasks of center C. Center C had the largest score differences, all of which were larger than two on a 10-point scale; center A had fewer and smaller score differences with values between 0.81 and 1.51 . 
Table 6. Means of total scores of the five major tasks of EE regional centers.

\begin{tabular}{|c|c|c|c|c|c|c|c|c|c|c|c|c|c|c|c|c|}
\hline \multirow{2}{*}{$\begin{array}{c}\text { Centers/Tasks } \\
\begin{array}{c}\text { EE regional } \\
\text { centers }\end{array}\end{array}$} & \multicolumn{4}{|c|}{$\begin{array}{c}\text { Mean Scores Rated by Members } \\
\text { of EE Regional Center Operation } \\
\text { Teams (Group I) }\end{array}$} & \multicolumn{4}{|c|}{$\begin{array}{c}\text { Mean Scores Rated by Members } \\
\text { of EE Institutions, Facilities, and } \\
\text { Venues } \\
\text { (Group II) }\end{array}$} & \multicolumn{4}{|c|}{$\begin{array}{l}\text { Differences in Means } \\
\text { (Group I-Group II) }\end{array}$} & \multicolumn{4}{|c|}{$\begin{array}{c}\text { Mean Scores Rated by All } \\
\text { Respondents of Both Groups }\end{array}$} \\
\hline & A & B & C & D & A & B & C & $\mathrm{D}$ & A & B & C & $\mathrm{D}$ & A & B & C & D \\
\hline $\begin{array}{l}\text { Academy } \\
\text { leadership }\end{array}$ & $\begin{array}{c}8.72 \\
(1.23)\end{array}$ & $\begin{array}{c}7.67 \\
(1.24)\end{array}$ & $\begin{array}{c}7.61 \\
(1.33)\end{array}$ & $\begin{array}{c}7.50 \\
(1.42)\end{array}$ & $\begin{array}{c}7.21 \\
(1.38)\end{array}$ & $\begin{array}{c}6.84 \\
(2.07)\end{array}$ & $\begin{array}{c}5.32 \\
(2.76)\end{array}$ & $\begin{array}{c}6.86 \\
(2.18)\end{array}$ & $1.51^{* *}$ & 0.83 & 2.29 & 0.64 & $\begin{array}{c}7.86 \\
(1.51)\end{array}$ & $\begin{array}{c}7.14 \\
(1.84)\end{array}$ & $\begin{array}{c}6.16 \\
(2.58)\end{array}$ & $\begin{array}{c}7.22 \\
(1.79)\end{array}$ \\
\hline $\begin{array}{l}\text { Capacity } \\
\text { building }\end{array}$ & $\begin{array}{c}8.56 \\
(1.04)\end{array}$ & $\begin{array}{c}7.67 \\
(1.03)\end{array}$ & $\begin{array}{c}8.06 \\
(1.16)\end{array}$ & $\begin{array}{c}7.78 \\
(1.00)\end{array}$ & $\begin{array}{c}7.75 \\
(1.26)\end{array}$ & $\begin{array}{l}7.26 \\
(2.00)\end{array}$ & $\begin{array}{l}5.81 \\
(2.86)\end{array}$ & $\begin{array}{c}7.79 \\
(1.31)\end{array}$ & 0.81 * & 0.41 & $\underset{* * *}{2.25}$ & -0.01 & $\begin{array}{c}8.10 \\
(1.23)\end{array}$ & $\begin{array}{c}7.41 \\
(1.71)\end{array}$ & $\begin{array}{c}6.63 \\
(2.60)\end{array}$ & $\begin{array}{r}7.78 \\
(1.13)\end{array}$ \\
\hline $\begin{array}{l}\text { Technological } \\
\text { support }\end{array}$ & $\begin{array}{c}7.56 \\
(1.89)\end{array}$ & $\begin{array}{l}7.00 \\
(2.03)\end{array}$ & $\begin{array}{l}7.61 \\
(2.25)\end{array}$ & $\begin{array}{c}6.89 \\
(2.08)\end{array}$ & $\begin{array}{c}6.71 \\
(1.43)\end{array}$ & $\begin{array}{c}6.77 \\
(1.91)\end{array}$ & $\begin{array}{c}5.52 \\
(2.69)\end{array}$ & $\begin{array}{c}6.64 \\
(2.06)\end{array}$ & 0.85 & 0.23 & $2.09^{* *}$ & 0.25 & $\begin{array}{l}7.07 \\
(1.67)\end{array}$ & $\begin{array}{c}6.86 \\
(1.94)\end{array}$ & $\begin{array}{l}6.29 \\
(2.72)\end{array}$ & $\begin{array}{l}6.78 \\
(2.04)\end{array}$ \\
\hline $\begin{array}{l}\text { Research and } \\
\text { evaluation }\end{array}$ & $\begin{array}{c}7.67 \\
(1.85)\end{array}$ & $\begin{array}{l}7.56 \\
(1.82)\end{array}$ & $\begin{array}{c}7.44 \\
(1.85)\end{array}$ & $\begin{array}{c}7.28 \\
(1.93)\end{array}$ & $\begin{array}{l}7.00 \\
(1.22)\end{array}$ & $\begin{array}{c}6.90 \\
(2.06)\end{array}$ & $\begin{array}{c}5.32 \\
(2.45)\end{array}$ & $\begin{array}{l}7.14 \\
(1.92)\end{array}$ & 0.67 & 0.66 & $2.12^{* *}$ & 0.14 & $\begin{array}{c}7.29 \\
(1.53)\end{array}$ & $\begin{array}{c}7.14 \\
(1.98)\end{array}$ & $\begin{array}{l}6.10 \\
(2.46)\end{array}$ & $\begin{array}{l}7.22 \\
(1.90)\end{array}$ \\
\hline $\begin{array}{l}\text { Dissemination } \\
\text { partnerships }\end{array}$ & $\begin{array}{c}8.78 \\
(0.94)\end{array}$ & $\begin{array}{c}8.28 \\
(0.96)\end{array}$ & $\begin{array}{c}8.56 \\
(0.86)\end{array}$ & $\begin{array}{c}8.28 \\
(1.27)\end{array}$ & $\begin{array}{c}7.46 \\
(1.28)\end{array}$ & $\begin{array}{c}7.26 \\
(1.98)\end{array}$ & $\begin{array}{l}5.65 \\
(2.76)\end{array}$ & $\begin{array}{c}7.64 \\
(1.91)\end{array}$ & $1.32^{* *}$ & $1.02 *$ & $\begin{array}{c}2.91 \\
* * *\end{array}$ & 0.64 & $\begin{array}{c}8.02 \\
(1.32)\end{array}$ & $\begin{array}{c}7.63 \\
(1.74)\end{array}$ & $\begin{array}{c}6.71 \\
(2.65)\end{array}$ & $\begin{array}{r}8.00 \\
(1.59)\end{array}$ \\
\hline
\end{tabular}

of post hoc multiple comparisons after a significant difference among the four EE regional centers in the task performance mean scores is detected by MANOVA. 
In the results of MANOVA, if a significant difference among the four centers in the scores of the five major tasks was detected, the mean scores among which the results of multiple post hoc comparisons indicate significant differences were bolded. No significant differences among the four centers in the scores of the five major tasks rated by the EE regional center operation team members were found (the column of Group I in Table 6), neither in those rated by the members of EE institutions, facilities and venues (the column of Group II in Table 6), though the $p$ value was slightly larger than the $\alpha$ level of 0.05 . When both groups of respondents were included in the sample of a MANOVA, significant score differences among these centers in each of the tasks emerged in the results of multiple post hoc comparisons. Most of these differences occurred between centers $A$ and $C$ in four tasks except technological support, as the bolded numbers in Table 6 indicate. Take the task of academic leadership for example, a significance difference between the mean score of center A (7.86) and that of center C (6.16) was found after multiple post hoc comparisons of four mean scores of the four centers. The mean scores of center D in capacity building (7.78) and dissemination partnership (8.00) were also significantly higher than those of center C (6.63 and 6.71 respectively). Among the four centers, center A obtained the highest mean scores rated by all respondents in all five major tasks with values between 7.07 and 8.10 whereas center $C$ had the lowest ones in all these tasks with values between 6.10 and 6.71 .

A few respondents from the EE institutions, facilities and venues left their anonymous comments in the evaluation on EE regional center performance (see Table 7). Most comments were left for centers $\mathrm{B}$ and $\mathrm{C}$, each receiving six critical comments, and only one comment was left for center A. These respondents were most responsive to the task of academy leadership and gave the fewest comments about research and evaluation, though a number of suggestions in the comments for other tasks were actually relevant to the research. Overall, these comments consisted of both practical suggestions for explicit objects and events and conceptual ideas about planning, collaborations, and operation. "Experience" was obviously an important keyword that was pointed out repeatedly in the comments for not only the center with significantly lower performance ratings but also another center.

Table 7. Comments of the respondents from EE institutions, facilities and venues on the performance in each of the five major tasks for respective EE regional centers.

\begin{tabular}{|c|c|}
\hline \multicolumn{2}{|r|}{ Academy leadership (comments for each center): } \\
\hline A & - More training workshops for EE personnel certification. \\
\hline $\mathrm{B}$ & $\begin{array}{l}\text { - } \quad \text { Provision of literature for professional advancement. } \\
\text { - } \quad \text { Capability in holistic planning to integrate resources and foster collaborations in the region. } \\
\text { - } \quad \text { The operation team lacks practical experiences. }\end{array}$ \\
\hline $\mathrm{C}$ & $\begin{array}{l}\text { - Stop organizing forums or coalition meetings that have no substantial effectiveness and only } \\
\text { discuss incentives. It is suggested that the center learn from other centers about how to hold } \\
\text { conferences, workshops, and training programs with a broadened horizon. } \\
\text { The activities and trainings are less integrated with educational practices and the organizers are } \\
\text { less informed about the international EE trends and have insufficient experiences in EE practices. } \\
\text { It is suggested that the center learn from the activities and trainings organized by the best center. } \\
\text { - The center is deficient in the leadership and expertise in EE. } \\
\text { - The manpower and capacity are needed for the realization of the set goals or it falls into a waste of } \\
\text { budget allocation and resources without the needed growth in any one center or personnel thereof. }\end{array}$ \\
\hline \multicolumn{2}{|r|}{ Capacity building (comments for each center): } \\
\hline B & - $\quad$ Collecting materials of EE facilities, venues, and institutions for sharing. \\
\hline $\mathrm{C}$ & $\begin{array}{l}\text { - The facilities and venues in the region are less mature and need expert capacity building and } \\
\text { training to broaden their visions. Nevertheless, the lecturers invited in the workshops are limited } \\
\text { to a few persons in the region who are less experienced in practical promotion of EE. It is felt this } \\
\text { becomes easily reduced to empty talk and has marginal benefits for the practitioners of EE venues. }\end{array}$ \\
\hline B & $\begin{array}{l}\text { - It should be done in accordance with the customs of users; communication via E-mailing is more } \\
\text { convenient for most users. }\end{array}$ \\
\hline
\end{tabular}


Table 7. Cont.

\begin{tabular}{|c|c|}
\hline \multicolumn{2}{|r|}{ Technological support (comments for each center): } \\
\hline $\mathrm{D}$ & $\begin{array}{l}\text { - The problems about which EE venue practitioners are most concerned include no more topics than } \\
\text { models of operation, development of programs, marketing, and teaching skills. The center should } \\
\text { conduct an analysis on these problems for the practitioners' references. Making public the records } \\
\text { of activities and annual data analysis on the outcomes of activities is also suggested. }\end{array}$ \\
\hline \multicolumn{2}{|r|}{ Research and evaluation (comments for each center): } \\
\hline B & $\begin{array}{l}\text { - Besides collecting data on occasions of meetings, online evaluation on EE regional center } \\
\text { performance is suggested. }\end{array}$ \\
\hline \multicolumn{2}{|r|}{ Dissemination partnerships (comments for each center): } \\
\hline B & - It is helpful that the center provided subsidies as regards to the needs of EE facilities and venues. \\
\hline $\mathrm{C}$ & $\begin{array}{l}\text { - An EE regional center should be a platform for partner interaction instead of an organization } \\
\text { whose merits are appraised just by the number of MOUs it signed with others. When the purposes } \\
\text { and items of collaboration of an MOU are unclear, it bears no physical meaning. }\end{array}$ \\
\hline $\mathrm{D}$ & $\begin{array}{l}\text { - The exchange activities among partners should not be merely the discussion at meetings without } \\
\text { the assignment of tasks and tracking the implementation of resolutions. } \\
\text { There should be a more specific model of collaboration as well as a mutual-beneficial mechanism } \\
\text { for the center and partners. } \\
\text { - We have a higher expectation for the EE regional center, which can supplement the studies that EE } \\
\text { facilities and venues often lack, such as in studies on action research, learning models, and } \\
\text { operational analysis. }\end{array}$ \\
\hline
\end{tabular}

\subsubsection{The Topics and Thematic Areas of Expertise in Need for Capacity Building or of Interest}

The members of EE facilities and venues were asked to pick one or more topics in which they needed for capacity building from five topics (Table 8). Programming and activity/curriculum design was the topic revealing the most interest; it accounted for $28.28 \%$ of total picks. The requirements for other topics, except for application for facility/venue certification, were approximately even, each with about $20 \%$ of total picks. Among the eight thematic areas of expertise listed in the Regulations Governing the Certification and Management of Environmental Education Personnel, respondents from EE facilities and venues expressed the most needs for building capacity or interests in the area of nature conservation ( 49 picks, $18.35 \%$ in Table 9 ). Other areas such as environmental/resource management and cultural preservation also obtained considerable picks, each accounting for at least $15 \%$.

Table 8. The topics that members of EE facilities/venues need for capacity building or for their interests.

\begin{tabular}{ccc}
\hline Topics & Picks & $\%$ \\
\hline Programming and activity/curriculum design & 56 & 28.28 \\
Teaching/guiding skills & 47 & 23.74 \\
Facility/venue operation and management & 41 & 20.71 \\
Campaign and marketing of activities & 42 & 21.21 \\
Application for facility/venue certification & 12 & 6.06 \\
\hline
\end{tabular}

Table 9. The thematic areas of expertise that members of EE facilities/venues need for capacity building or for their interests.

\begin{tabular}{ccc}
\hline Areas & Counts & $\%$ \\
\hline School and social EE & 34 & 12.73 \\
Climate change & 34 & 12.73 \\
Disaster prevention and rescue & 17 & 6.37 \\
Nature conservation & 49 & 18.35 \\
Nuisance control & 19 & 7.12 \\
Environmental/resource management & 41 & 15.36 \\
Cultural preservation & 41 & 15.36 \\
Community participation & 32 & 11.99 \\
\hline
\end{tabular}




\section{Discussion}

\subsection{Tasks and Target Subjects Involved in Role Positioning of EE Regional Centers}

Giving emphasis to the functions of an EE center is influenced by needs-assessed resources available, expertise of the staff, and the role of the center as perceived by the host institution [18]. Facing the challenge to promote EE in a region covering several counties and cities, most EE regional center operation team members recognized that meeting and linking the environmental educators across the region is presently supposed to be the task that lays a foundation for successful practices of the centers. This could explain the result that the task of dissemination partnerships had the largest perceived relative importance among the five major tasks. It could involve investing effort in maintaining social communities, which Liang [24] considered crucial for Taiwan's EE regional centers to facilitate the integration of EE resources in the region and support local EE needs. These university-based and faculty-operated EE regional centers play a leading role in networking multiple partners as Sabir's [46] (p. 65) example of regional centers for expertise (RCE) on education for sustainable development (ESD) demonstrates that academia should aim mainly to set a framework of the network "in a way that gives direction and purpose to the engagement agenda". Additionally, many of the EE regional center operation team members should be well-informed about the U.S. EPA's EECapacity project from which Taiwan's EE regional centers emulated the major tasks and therefore chose capacity building as an important task. Moreover, they could share a common belief that the environmental educators across the region must be well-equipped with the capacity necessary for quality EE in order to help EE regional centers promote $\mathrm{EE}$.

The result that research and evaluation were a task given less importance could be due to the limited available resources at the current stage of the EE regional center development. However, a survey indicates that the nature center operators have begun paying attention to this task [9]. For university-based EE centers like Taiwan's EE regional centers, research (in a broad sense including evaluation) is worth considering since it has been an essential role for universities participating in ESD $[37,47,48]$ and benefits the centers with respect to professional development and partnership with practitioners and educators. Such research is certainly not that undertaken in the ivory tower but a co-research between the host university of an EE regional center and its EE partners outside of academia, which is in line with "a practical action-based approach to teaching and research" that many practitioners advocate due to the nature of EE [49] (p. 306). In co-research, the EE regional center and university might obtain new insights from the regional process in terms of knowledge base, theory building and methodological developments [47]. It also represents a two-way integration process between the EE regional center/university and social communities of EE practitioners and educators where case studies on regional transitions are integrated into research [37] and research experiences are integrated into the practice of service to the communities [49].

As the term "center for expertise" implies, regional centers for expertise (RCE) on ESD is conceptually a strategy-oriented center and the five major tasks of EE regional centers set by Taiwan's EPA are essentially the work in which environmental educators rather than the general public feature largely. These both confer a strategic inclination to the EE regional centers with respect to their role position. In determining the role of EE regional centers between a practice-oriented and a strategy-oriented one, results of this study, however, indicate that most EE regional center operation team members took divergent stances, though they were averaged into a mean point denoting a minor tendency toward the practice-orientation side. This coincides with the remarkably subjective nature of thinking about EE that Shephard and Furnari [50] observed in the literature. On one hand, it reaches the subjects in Figure 2, and the reasons listed in Table 4 show that they agreed schools are better served by the organizations in the system of the Ministry of Education and that the general public is not a major target of subjects of EE regional centers but one of the EE facilities/venues, suggesting a role different from the practices of providing EE programs to students and citizens. On the other hand, some of them also highly supported the notion that "an EE regional center is supposed to proactively 
and directly provide programs and services to various subjects as best it can" and consent to the idea that having substantial practical experience in this regard is a prerequisite for the expertise of an EE regional center. The subtle predisposition toward a practice-oriented role of the EE regional center could be associated with both an expectation for a more complete and larger center with more resources and more importantly, a latent belief in the value of practicing EE. In the mindsets of some EE regional center operation team members, practices and experience matter more than abstract, prescriptive guidance in EE.

The operation team members of EE regional centers thought it necessary to reach subjects such as corporate groups and NGOs, and this seemingly represents their ideal of the extension and popularization of EE to a wider range of categories of subjects through more practices of promotion. Alternatively, it could also be regarded as an innovative attempt to offer expertise and guidance in EE strategies to these atypical subjects by collaborating with them. On a perspective of the tenet of sustainable development goal (SDG) 4 (quality education), reaching corporate groups is reasonable in that the goal widens the scope of education beyond the traditional focus of the formal schooling to the lifelong learning in various settings [51]. Perplexingly, the general public is least considered as the subject to be directly reached, but a considerable number of the members of EE regional center operation teams also agreed that the EE regional centers are obligated to provide EE to various general public groups as best they can. It is speculated that the members perceived the issue of subjects to be reached as strategic planning for more extensive EE, while bearing in mind that all citizens are their target audience and need EE. The strategy makes sense, as there was a demand for more programs of EE centers for adults outside schools [40]. Still, providing EE for citizens of all ages is as much an obligation of EE regional centers as one of the approaches to professional development for EE regional centers. Lastly, the idea of the industrialization of EE is debatable, and so is the question whether it can be incorporated as one of the tasks of future EE regional centers. This novel idea stems from an expectation of Taiwan's EPA to increase both the participation of non-governmental sectors in social $\mathrm{EE}$ and the economic incentive for environmental educators who consider investing themselves in this "business". The EE regional center operation team members held mixed attitudes toward it and those who had reservations about it could have a similar concern as Jones and Moore [52] who cautioned that the distortion of EE could be caused by the use of corporate or development language and models.

The evaluation results show that respondents from EE facilities/venues and institutions were quite demanding to the performance of the EE regional centers in their regions as indicated by the generally lower ratings they gave than those the EE regional center operation team members gave to all tasks of all centers. This relative satisfaction of EE regional center operation teams with the task performance is no exception to the common result in the research of self-other comparison of performance ratings that service providers' self-ratings usually surpass other- or customer-ratings $[53,54]$. In view of our observation and understanding of these team members, they know well about how much work they did on these tasks. So it is rather a matter of leniency, a major factor of higher self-ratings [55], than a result of the circumstance that customers cannot observe all aspects of the behaviors of service providers [56]. However, since Folkes [57] explained that when the level of service performed is lower than customers' expectations, they would evaluate the service as low. It must be acknowledged that the services that EE regional center teams provided could not meet the needs and expectations of the EE practitioners and environmental educators. The team members could also receive inadequate feedback from their customers, leading them to rate their performances higher [40].

\subsection{Expertise Development of Operation Teams of EE Regional Centers}

A problem of the expertise and experience of EE regional center operation teams in EE is manifested as some practitioners from EE facilities and venues criticized in their feedback. Indeed, as one of the major tasks of EE regional centers, academy leadership prompts the examinations of EE practitioners and environmental educators who expect EE expertise from EE regional centers. According to Hoffman et al. [58] (p. 131), "experts" have been selected on the basis of professional criteria (graduate degrees, 
training experience, publication record, memberships in professional societies, licensing, etc.). Against these criteria, certain practitioners and environmental educators might not be satisfied with a few EE regional centers hosted by professors with an "environmental" rather than an "educational" background. For full-time professional leadership in EE, John Disinger believed "professional" should be defined as synonymous with professional education, though such leadership is hard to obtain [59].

Much of the leadership in post-secondary environmental education has come from people who are not educators, but are instead employed as specialists in one or another academic discipline.... Practically nowhere is it their primary responsibility. Nor is education their primary expertise. [59] (p. 7)

Even an expert who knows much about the field could lack personal experience in the field, which Mieg [60] described as "notoriously" the case in academia. In Disinger and Roth's [61] view, professional leadership in EE comes from individuals who are experienced and active in the field. As such, it is argued that the expertise in EE can be complemented by experiences in EE practices and collaboration with practitioners and environmental educators in EE research. Van de Wiel, Szegedi, and Weggeman [62] pointed out that a key concept in literature on how professionals learn from their experiences is reflection, a decisive stage in a process that educators of sustainable development should follow in a competence framework for their training [63]. They showed that talking with colleagues and self-reflection are important activities for professional development and competence-building. From this reflective dialogue [64] or collaborative reflection, professional identity could form as well [65]. Hence, mutual learning among members of different EE regional center operation teams in both formal, regular meetings and on informal occasions is encouraged. This is supported by Li and Krasny's observation that the increased interactions among diverse groups of environmental educators in professional development programs result in the creation of practice innovations [66], which can be seen as an evidence of advanced competence.

In a case of an RCE on ESD, the necessity of a more comprehensive education-based approach is emphasized [67], which is particularly true in the context of SDG 4 (quality education) that accentuates education as the heart of sustainable development [68] as well as the golden thread running through all SDGs [69]. It also echoes the evaluation results that programming and activity/curriculum design is the most needed topic in capacity building for practitioners and environmental educators of EE facilities and venues. In response to this result, the pedagogical approaches essential for the achievement of SDGs is implicative. Rieckmann [70] suggested that such teaching should be designed as learner-centered, action-oriented and transformative, with educators helping learners construct their own knowledge base, creating a learning environment that increases their experiences, and empowering them to change their worldviews. Particularly illuminating for the EE regional centers tinged with non-formal EE in Taiwan is that learners' understanding of SDGs is developed through continuous learning not only inside but also outside the classroom and supported by both in-class experiences and other formative events in their lives [71]. The EE regional center operation team members whose expertise is non-educational need to think outside the box of their academic specialties when they learn from members of other operation teams or experienced environmental educators in the field to put their projects into practice in an educational way. Additional learning opportunity also exists in the collaboration on the co-research discussed above since Walter, Helgenberger, Wiek, and Roland [72] indicated that the faculty, i.e., those who lead the EE regional center operation teams in this study, and the practitioners both learn lessons with this opportunity. Over time and in a mundane sense, published research outcomes should add to the credit of the members of an EE regional center operation team as experts in EE.

With the understanding of expertise development process, the practice- and strategy- oriented roles of EE regional centers are rather a staged progress of advancement or maturation from practice-orientation to strategy-orientation than a one-for-all choice of either role. The way regional EE center operation teams learn in this process is essentially situated learning, in which knowledge is constructed as a result of learners' social interactions with others in the contexts they are situated 
in [73-75]. The concept of legitimate peripheral participation that Lave and Wenger [74] proposed for such learning offered a summative theoretical framework that integrates the key points we argued for the expertise development of the regional EE center operation teams. This practice-based theory emphasizes that learners grow by participating in authentic activities, or "learning-in-working" [75], in a community of practice. These activities enable learners to see the perspectives of experts and act meaningfully in handling the practices [73]. Based on the theory, those who are not just observers outside but work in the community of practice are legitimate learners, and as newcomers, the work they do is peripheral in the sense that it is partial, operational level practices of the community. Through the interactions with the experienced members of the community, learners gain more experiences, are gradually engaged in the core practices, and eventually become experts who possess "knowledgeable skills" [74].

It is envisaged that the EE practitioners, environmental educators, and the operation team members of regional EE centers comprise a community of practice in a broad sense. Learning from and collaborating with these practitioners and environmental educators on co-research, as previously suggested for lower rated EE regional centers, are the activities involving social interactions that situated learning theory emphasizes as facilitating expertise development. After implementing more $\mathrm{EE}$ practices at an operational level, the regional $\mathrm{EE}$ center operation teams with inadequate experiences could substantiate their knowledge base and be increasingly competent at mastering most EE practices, and then are advanced to an expert status where they are qualified to provide guidance in EE at a strategic level. This process parallels the constructivist learning that Vare et al. [63] indicated as a characteristic in the professional development of educators of sustainable development, where learners practice the very competence that they will teach in the future. Again, reflection is also an important step in the methods of situated learning [76], including comparing with experts [77]. In light of the evaluation result of the four EE regional centers, whether educational approaches were adopted in our EE practices and what values rooted in the practices of experienced environmental educators we recognized, are pivotal reflective questions for operation teams in comparing themselves with the center team rated highest and reputed as experts.

As the EE regional centers have sufficient expertise to assume a strategy-oriented role in regional $\mathrm{EE}$, two issues deserve consideration. That is, the grasp of sustainability and community, which Hesselink, van Kempen, and Wals [78] indicated is crucial to successful EE practices. Firstly, since an EE center as a change agent can "translate" national and international environmental discourse into local contexts [22], the EE regional center might help to convert the policies, such as SDGs, and values of sustainability to regional initiatives. In this regard, they should be capable of working with real regional/local problems and socially participatory approaches [78,79]. In addition to the goals in environmental sustainability including SDGs 7 (affordable and clean energy), 13 (climate action), 14 (life under water), and 15 (life on land), these centers are suitable for mainstreaming specific SDGs in accordance with the status of development in Taiwan. For example, in reaching the subjects of corporate, SDG 12 (responsible consumption and production) would be an applicable context in which the EE regional centers collaborate with and engage corporate in sustainability learning. Secondly and relatedly, it is important to improve the relations with local communities in bringing about these changes [22] and it correspondingly strengthens the necessity to actually implement the task of partnership networking of EE regional centers at present. The resultant stronger and closer connections with communities should pave the way for achieving SDG 11 (sustainable communities and cities).

Due to limited resource availability, this study simply conducted a summative evaluation that used the assessments made by the significant participants and operation team members of the EE regional centers based on their experiences and did not apply a research design in the evaluation. Considering these EE practitioners and environmental educators who are knowledgeable about and engaged in the activities of EE regional centers as some kind of experts, this evaluation can be an estimation by experts that draws on their knowledge, experience and intuition to generate a summarized judgment [80]. 
It also attempts to extend the scope of EE center evaluation from programs to organizations, i.e., the centers themselves. Kopar [81] held that environmental centers could conduct objective organizational evaluation, though with constraints. As an EE organization, like an EE regional center, has dimensions of persons, operations, and programs, which remain to be the major focus of evaluation, one of the challenges for future studies would be the aggregation of the merit of several EE programs it provided over the time-span of evaluation. The method of meta-analysis is suggested to synthesize the results of individual program evaluation $[7,82]$.

\section{Conclusions}

At the present stage of the development of Taiwan's EE regional centers, in the views of EE regional center operation team members, dissemination partnerships are the most important task among the five tasks assigned by Taiwan's EPA. They took different stands on whether the functional role of EE regional centers should be practice-oriented or strategy-oriented, resulting in a roughly middle position between the two orientations, which literally falls on the practice-oriented side. Yet, most of them cited corporate groups and NGOs as the main group of target subjects that their centers should work with closely, while the general public, a major group of subjects of conventional EE centers, was cited the least. Implicit in this result could be a strategic perspective as they agreed with the significance of NGOs in non-formal EE.

In the evaluation on EE regional center performance made by the practitioners and educators from EE institutions, facilities and venues in each region, the performance levels of the four centers varied noticeably. Some centers received higher ratings overall and some were relatively inadequate in most of the five mandated tasks. Most of the criticisms given by the respondents pertained to the task of academic leadership where practical experience of the EE regional center in EE was a problem that they were greatly concerned about. It is argued that the higher-ordered, strategy-oriented role of an EE regional center should not be simply assigned by policies but upheld by its expertise in EE, developed from the accumulated experiences in EE practices and co-research with regional practitioners and environmental educators. Respondents' valuable comments suggested that they need capacity building mostly in the topic of programming and activity/curriculum design, and the expertise of some EE regional centers was unsatisfactory. Since these capacity-building needs are practice-oriented, the EE regional centers are obliged to be equipped with sufficient practical experiences in educational approaches so that they can be adequate for a future strategic role as a guidance provider in regional EE. It is necessary for the expertise of some EE regional centers to grow through on-site experiences in providing EE programs for the general public and other EE practices at the present stage. By then, a title of "Regional Center of Expertise in Environmental Education," as Jickling and Wals [83] suggested, could be conceptually more appropriate for the EE regional centers in Taiwan. These university-based, faculty-operated EE regional centers should favorably perform the task of research to contribute studies that empirically support the strategies they propose for the professional development of educators, EE facility operation, and the design of programs and materials. To broaden the scope of future research in EE centers, it is suggested that some attention is diverted from the programs of the centers to the capacity and effectiveness of the EE organizations per se.

Some limitations of this study must be acknowledged. In-person interviews are not employed to explore in-depth views of significant persons involved in the operation of EE regional centers. With an online survey, respondents may hesitate to leave comments or only to leave simplified comments, lacking qualitative data that could be informative to the interpretation of the results of quantitative analysis. During the survey, there were only a few EE facilities and venues in one region, resulting in a smaller sample of the EE practitioners and environmental educators from that region. As regards to the theory construction, due to the scarcity of empirical studies focusing on the roles, operations, and practices of EE centers, the theoretical basis in this field is yet to be well developed. Limitations of applying theories in other fields to analyze the issues of expertise development in EE in this study should be noted. 
Funding: This research received no external funding.

Conflicts of Interest: The authors declare no conflict of interest.

\section{Appendix A. Questionnaire for the Operation Team Members of EE Regional Center}

1. The role positioning of EE regional center

1-1. Based on the status quo of EE in Taiwan, what do you think are the percentages of importance for the five major tasks, respectively, in the total tasks of an EE regional center? (Fill in each of the blanks with a number)

(1) Academy leadership: __ \%

(2) Capacity building: _ _ \%

(3) Technological support: __ \%

(4) Research and evaluation: __ \%

(5) Dissemination partnerships: __ \%

1-2. On a spectrum of roles with two ends, "practice-oriented" and "strategy-oriented," which are defined as*:

- A practice-oriented EE regional center places emphasis on the ideal of popularization of $\mathrm{EE}$ and realizing actions in EE, specifies more types of organizations and populations as major targets, and provides proactive and direct services or programs/initiatives to these targets, although requiring more manpower, budget, and other resources.

- A strategy-oriented EE regional center underscores the ideas, methods, and system operations of EE and specifies fewer types of organizations and populations as major targets to provide them with proactive and direct services (guidance/capacity building). It passively accepts inquiries from, participates in or provides indirect services to other types of organizations and populations on demand, so might require less resources.

Which end do you think the EE regional centers should be positioned toward (without considering the limitations of budget, manpower, and other resources)?

$$
\text { Practice-oriented } \leftarrow 1234567 \rightarrow \text { Strategy-oriented }
$$

1-3. According to your view on the above positioning of the role of an EE regional center, please select from the following categories of subjects that the center should reach proactively and directly. (More than one category can be selected).

$\square$ Corporate $\square$ Schools $\square$ NGOs $\square$ EE personnel $\square$ General public

$\square$ Others:

1-4. Please indicate the extent to which you agree with the following reasons for the subjects to be reached by EE regional centers. 


\begin{tabular}{|c|c|c|c|c|c|c|}
\hline \multirow[b]{2}{*}{1.} & \multirow[t]{2}{*}{ Reasons } & \multicolumn{3}{|c|}{$\begin{array}{l}\text { Strongly } \\
\text { disagree }\end{array}$} & \multicolumn{2}{|c|}{$\begin{array}{r}\text { Strongly } \\
\text { agree }\end{array}$} \\
\hline & & 1 & 2 & 3 & 4 & 5 \\
\hline 2. & $\begin{array}{l}\text { As schools at all levels are numerous, they should be provided with } \\
\text { services by the organizations in the system of The Ministry of } \\
\text { Education. The EE regional centers and those organizations should } \\
\text { work for EE in cooperation with a division of labor. }\end{array}$ & 1 & 2 & 3 & 4 & 5 \\
\hline 3. & $\begin{array}{l}\text { The role position of EE regional centers would not be different from } \\
\text { that of the numerous EE facilities/venues if they invested more } \\
\text { effort and resources in providing EE proactively and directly to the } \\
\text { general public. }\end{array}$ & 1 & 2 & 3 & 4 & 5 \\
\hline 4. & $\begin{array}{l}\text { Having substantial practical experiences in proactively and directly } \\
\text { providing programs and services to the general public and schools } \\
\text { is a prerequisite for the expertise of an EE regional center. }\end{array}$ & 1 & 2 & 3 & 4 & 5 \\
\hline 5. & $\begin{array}{l}\text { The EE institutions are statutory institutions for EE personnel } \\
\text { training; the function of EE regional centers would overlap that of } \\
\text { EE institutions if EE regional centers proactively and directly } \\
\text { provided capacity building/training programs. }\end{array}$ & 1 & 2 & 3 & 4 & 5 \\
\hline 6. & $\begin{array}{l}\text { Seeking corporate groups to invest resources or participate in the } \\
\text { promotion of EE is one of the important and major jobs of EE } \\
\text { regional centers. }\end{array}$ & 1 & 2 & 3 & 4 & 5 \\
\hline 7. & $\begin{array}{l}\text { Corporate groups are profit-oriented so one should refrain from too } \\
\text { many proactive and direct interactions with corporations in } \\
\text { promoting educational work. }\end{array}$ & 1 & 2 & 3 & 4 & 5 \\
\hline 8. & $\begin{array}{l}\text { NGOs are important promoters in non-formal EE so the EE regional } \\
\text { centers should proactively work with them. }\end{array}$ & 1 & 2 & 3 & 4 & 5 \\
\hline 9. & $\begin{array}{l}\text { The issues about which NGOs are concerned involve controversies } \\
\text { of environmental policies and are hence not compatible with the } \\
\text { educational nature of EE regional centers. They are not in the } \\
\text { categories of organizations that must be reached. }\end{array}$ & 1 & 2 & 3 & 4 & 5 \\
\hline
\end{tabular}

Other reasons:

1-5. "Fostering the industrialization of EE in the region is one of the major tasks in which future EE regional centers should place their efforts".

$$
\text { Strongly disagree } \leftarrow 12345 \rightarrow \text { Strongly agree }
$$

1-6. As far as the legal status of EE regional centers, you consider that they should

$\square$ Remain to be established by the Taiwan EPA projects

$\square$ Be prescribed in the EE Act

Other:

2. Evaluation on the performances of EE region centers

2-1. Please rate each center on its overall performance in the task of "Academy leadership". 


\begin{tabular}{lcccccccccc}
\hline \multicolumn{1}{c}{ Centers } & Low & & & & & & & High \\
\hline Northern EE regional center & 1 & 2 & 3 & 4 & 5 & 6 & 7 & 8 & 9 & 10 \\
\hline Eastern EE regional center & 1 & 2 & 3 & 4 & 5 & 6 & 7 & 8 & 9 & 10 \\
\hline Southern EE regional center & 1 & 2 & 3 & 4 & 5 & 6 & 7 & 8 & 9 & 10 \\
\hline Central EE regional center & 1 & 2 & 3 & 4 & 5 & 6 & 7 & 8 & 9 & 10 \\
\hline
\end{tabular}

2-2. Please rate each center on its overall performance in the task of "Capacity building".

\begin{tabular}{lcccccccccc}
\hline \multicolumn{1}{c}{ Centers } & Low & & & & & & & High \\
\hline Northern EE regional center & 1 & 2 & 3 & 4 & 5 & 6 & 7 & 8 & 9 & 10 \\
\hline Eastern EE regional center & 1 & 2 & 3 & 4 & 5 & 6 & 7 & 8 & 9 & 10 \\
\hline Southern EE regional center & 1 & 2 & 3 & 4 & 5 & 6 & 7 & 8 & 9 & 10 \\
\hline Central EE regional center & 1 & 2 & 3 & 4 & 5 & 6 & 7 & 8 & 9 & 10 \\
\hline
\end{tabular}

2-3. Please rate each center on its overall performance in the task of "Technological support".

\begin{tabular}{lcccccccccc}
\hline \multicolumn{1}{c}{ Centers } & Low & & & & & & & High \\
\hline Northern EE regional center & 1 & 2 & 3 & 4 & 5 & 6 & 7 & 8 & 9 & 10 \\
\hline Eastern EE regional center & 1 & 2 & 3 & 4 & 5 & 6 & 7 & 8 & 9 & 10 \\
\hline Southern EE regional center & 1 & 2 & 3 & 4 & 5 & 6 & 7 & 8 & 9 & 10 \\
\hline Central EE regional center & 1 & 2 & 3 & 4 & 5 & 6 & 7 & 8 & 9 & 10 \\
\hline
\end{tabular}

2-4. Please rate each center on its overall performance in the task of "Research and evaluation".

\begin{tabular}{lcccccccccc}
\hline \multicolumn{1}{c}{ Centers } & Low & & & & & & & High \\
\hline Northern EE regional center & 1 & 2 & 3 & 4 & 5 & 6 & 7 & 8 & 9 & 10 \\
\hline Eastern EE regional center & 1 & 2 & 3 & 4 & 5 & 6 & 7 & 8 & 9 & 10 \\
\hline Southern EE regional center & 1 & 2 & 3 & 4 & 5 & 6 & 7 & 8 & 9 & 10 \\
\hline Central EE regional center & 1 & 2 & 3 & 4 & 5 & 6 & 7 & 8 & 9 & 10 \\
\hline
\end{tabular}

2-5. Please rate each center on its overall performance in the task of "Dissemination partnerships".

\begin{tabular}{lcccccccccc}
\hline \multicolumn{1}{c}{ Centers } & Low & & & & & & & High \\
\hline Northern EE regional center & 1 & 2 & 3 & 4 & 5 & 6 & 7 & 8 & 9 & 10 \\
\hline Eastern EE regional center & 1 & 2 & 3 & 4 & 5 & 6 & 7 & 8 & 9 & 10 \\
\hline Southern EE regional center & 1 & 2 & 3 & 4 & 5 & 6 & 7 & 8 & 9 & 10 \\
\hline Central EE regional center & 1 & 2 & 3 & 4 & 5 & 6 & 7 & 8 & 9 & 10 \\
\hline
\end{tabular}

3. Demographics

3-1. Age: ; Gender: $\square$ Male $\square$ Female; Education:

3-2. Number of year(s) since you obtained a certificate of EE personnel $\square$ Not a holder of the certificate $\square$ It has been _ _ years

3-3. Position in the operation team: $\square$ Project host/coordinator/manager $\square$ Project Assistant $\square$ Other: 
*A figure the same as Figure 1 in Section 4.2.2 of the main text of this paper is also presented in the original questionnaire. It is omitted here to save space.

\section{Appendix B. Questionnaire for the Members (Practitioners/Educators) of EE Institutions and Facilities/Venues}

0. Please indicate the region you have been living in:

$\square$ Northern $\square$ Eastern $\square$ Southern $\square$ Central

1. Evaluation on the performances of the EE region center in your region Based on your experiences in working with the center or participating in its activities, please rate the overall performances in each of the tasks for the center:

\begin{tabular}{|c|c|c|c|c|c|c|c|c|c|c|}
\hline Centers & Low & & & & & & & & & High \\
\hline $\begin{array}{l}\text { Academy leadership: absorbing international advances that then } \\
\text { go through domestic conversions to develop expert EE strategies. }\end{array}$ & 1 & 2 & 3 & 4 & 5 & 6 & 7 & 8 & 9 & 10 \\
\hline $\begin{array}{l}\text { Capacity building: increasing the professional competencies, } \\
\text { attitude, and techniques of environmental educators to make } \\
\text { them models. }\end{array}$ & 1 & 2 & 3 & 4 & 5 & 6 & 7 & 8 & 9 & 10 \\
\hline $\begin{array}{l}\text { Technological support: developing technology-aided teaching } \\
\text { methods that respond to environmental changes and technology } \\
\text { advances. }\end{array}$ & 1 & 2 & 3 & 4 & 5 & 6 & 7 & 8 & 9 & 10 \\
\hline $\begin{array}{l}\text { Research and evaluation: devising operation systems for EE } \\
\text { institutions, mechanisms of market needs for EE personnel, } \\
\text { integrated management tools and performance evaluation } \\
\text { systems for EE regional centers. }\end{array}$ & 1 & 2 & 3 & 4 & 5 & 6 & 7 & 8 & 9 & 10 \\
\hline $\begin{array}{l}\text { Dissemination partnerships: networking with local partners and } \\
\text { forming social communities on EE to promote regional EE. }\end{array}$ & 1 & 2 & 3 & 4 & 5 & 6 & 7 & 8 & 9 & 10 \\
\hline
\end{tabular}

2. The topics in need for capacity building or of interest. (More than one topic can be selected).

$\square$ Programming and activity/curriculum design $\square$ Teaching/guiding skills

$\square$ Facility/venue operation and management $\square$ Campaign and marketing of activities

$\square$ Application for facility/venue certification $\square$ Others:

3. The thematic areas of expertise in need for capacity building or of interest. (More than one topic can be selected).

$\square$ School and social EE $\square$ Climate change $\square$ Disaster prevention and rescue

$\square$ Nature conservation $\square$ Nuisance control $\square$ Environmental/resource management

$\square$ Cultural preservation $\square$ Community participation

4. Demographics

4-1. Age: __ _ Gender: $\square$ Male $\square$ Female; Education:

4-2. Number of year(s) since you obtained a certificate of EE personnel

$\square$ Not a holder of the certificate $\square$ It has been __ years

4-3. Position in the institutions/facilities/venues: $\square$ Senior manager $\square$ Middle manager

Administration staff $\square$ EE teachers

\section{References}

1. Chou, J.; Lin, M.-R. A Planning Research on Local Environmental Learning Centers: An Example of Taichung Metropolis; Report of Commissioned Research Project, No. 88000057; Ministry of Education: Taipei, Taiwan, 2000.

2. Liang, S.-W.; Hsu, J.-C. Adult's Environmental Literacy Survey Project; Report of Commissioned Project, No. EPA-102-EA03-03-A260; Environmental Protection Administration, Executive Yuan: Taipei, Taiwan, 2013. 
3. Mochizuki, Y.; Fadeeva, Z. Regional centres of expertise on education for sustainable development (RCEs): An overview. Int. J. Sustain. High. Educ. 2008, 9, 369-381. [CrossRef]

4. Internet Archive. 2017. Available online: https://web.archive.org/web/20170705061429/http://www.eecapacity. net/activities (accessed on 5 July 2017).

5. Environmental Protection Administration (EPA). An Instruction to Bidders about the Review and Selection of the Commissioned Case on "Project Work Plan of Establishing the Northern Environmental Education Regional Center"; EPA, Executive Yuan: Taipei, Taiwan, 2014.

6. Yanniris, C. 20+ years of environmental education centers in Greece: Teachers' perceptions and future challenges. Appl. Environ. Educ. Commun. 2015, 14, 149-166. [CrossRef]

7. O'Donoghue, R.; Fadeeva, Z. Enhancing monitoring and evaluation practices in RCEs. In Building A Resilient Future Through Multistakeholder Learning and Action: Ten Years of Regional Centres of Expertise on Education for Sustainable Development; Fadeeva, Z., Payyappallimana, U., Tabucanon, M., Chhokar, K.B., Eds.; United Nations University Institute for the Advanced Study of Sustainability: Tokyo, Japan, 2014; pp. 161-179.

8. Medir, R.M.; Heras, R.; Geli, A.M. Guiding documents for environmental education centres: An analysis in the Spanish context. Environ. Educ. Res. 2014, 20, 680-694. [CrossRef]

9. Lee, C.W.; Li, C.; Liu, S.T. Service effectiveness of the nature centers for sustainability of environmental education and forest policy implications. Sustainability 2019, 11, 2457. [CrossRef]

10. Cha, S.C.; Jung, G.I.; Lee, K.M.; Oh, C.G.; Chang, Y.-H.; Lee, S.W. A study on functions of the environmental education centers in accordance with hierarchy. Environ. Educ. 2016, 29, 233-250.

11. Browning, M.; Stern, M.; Ardoin, N.M.; Heimlich, J.E. Factors that contribute to community members' support of local nature centers. Environ. Educ. Res. 2016, 24, 326-342. [CrossRef]

12. Browning, M.; Stern, M.; Ardoin, N.M.; Heimlich, J.E.; Petty, R.; Charles, C. Investigating the sets of values that community members hold toward local nature centers. Environ. Educ. Res. 2016, 23, 1291-1306. [CrossRef]

13. Pitoska, E.; Lazarides, T. Environmental education centers and local communities: A case study. Procedia Technol. 2013, 8, 215-221. [CrossRef]

14. Ballantyne, R.; Packer, J. Promoting learning for sustainability: Principals' perceptions of the role of outdoor and environmental education centres. Aust. J. Environ. Educ. 2006, 22, 15-29. [CrossRef]

15. Erickson, E.; Erickson, J. Lessons learned from environmental education center directors. Appl. Environ. Educ. Commun. 2006, 5, 1-8. [CrossRef]

16. Simmons, D.A. Are we meeting the goal of responsible environmental behavior? An examination of nature and environmental education center goals. J. Environ. Educ. 1991, 22, 16-21. [CrossRef]

17. Wilson, T.; Martin, J. Centers for Environmental Education: Guidelines for Success. In ERIC Database ED350145; Western Kentucky University: Bowling Green, OH, USA, 1991.

18. Wilson, T.L. The TVA Network of Centers for Environmental Education: An Examination of Factors That Contribute to Success. Ph.D. Thesis, Ohio State University, Columbus, OH, USA, 1993.

19. Padalino, J.J. National and regional centers for EE: Following up on the recommendations of the first national congress for environmental education futures-Policies and practices. In International Perspectives on Environmental Education: Issues and Actions. Selected Papers from the Thirteenth Annual Conference of the North American Association for Environmental Education; Cox, D.A., Stapp, W.B., Eds.; North American Association for Environmental Education: Troy, NY, USA, 1986; pp. 152-156.

20. Viloria, L.A. A network of regional centres of environmental education and training: A strategy for developing countries. Mar. Pollut. Bull. 1991, 23, 633-635. [CrossRef]

21. Meichtry, Y.; Harrell, L. An environmental education needs assessment of K-12 teachers in Kentucky. J. Environ. Educ. 2002, 33, 21-26. [CrossRef]

22. Nomura, K.; Hendarti, L.; Abe, O. NGO environmental education centers in developing countries: Role, significance and keys to success, from a "change agent" perspective. Int. Rev. Environ. Strateg. 2003, 4, 165-182.

23. Chao, Y.-L.; Kim, H.K.; Kim, C.K. A comparison of the regional environmental education centers in Korea and Taiwan: Systems, roles, and practices. J. Environ. Educ. Res. 2018, 14, 127-158.

24. Liang, M.H. Research on a University as an Environmental Education Regional Center Involved in the Implementation of Environmental Education with Local Government; Final Report; Research Project of the Ministry of Science and Techonology: Taipei, Taiwan, 2015. 
25. Hsu, M.-Y.; Tang, Y.-J. Exploring the collaboration relationships with partner organizations of environmental education regional centers of the environmental protection administration. New Horiz. Bimonth. Teach. Taipei 2017, 1-7.

26. Chiang, P.-Y. The Evaluation of Central Environmental Education Regional Center's Operating Mechanisms and Effectiveness. Master's Thesis, National Taichung University of Education, Taichung, Taiwan, 2016.

27. Minnesota Environmental Education Advisory Board. A GreenPrint for Minnesota: State Plan for Environmental Education; Office of Environmental Education, Minnesota Department of Education: St. Paul, MN, USA, 1993.

28. Smaldone, D.; Dey, S.E. Developing a successful state-level environmental education organization: A nationwide assessment. Appl. Environ. Educ. Commun. 2010, 9, 159-172. [CrossRef]

29. Fadeeva, Z.; Mochizuki, Y. Roles of regional centres of expertise on education for sustainable development: Lessons learnt in the first half of the UNDESD. J. Educ. Sustain. Dev. 2010, 4, 51-59. [CrossRef]

30. Judy, J.M. Centers for Environmental Education: The Tennessee Valley Authority Model. In Case Studies in Environmental Education; Tennessee Valley Authority: Knoxville, TN, USA, 1993.

31. Center for Environmental Education. 2020. Available online: https://nku.edu/academics/coe/centers/enved. html (accessed on 15 February 2020).

32. Murga-Menoyo, M.A. Educating for local development and global sustainability: An overview in Spain. Sustainability 2009, 1, 479-493. [CrossRef]

33. Romi, S.; Schmida, M. Non-formal education: A major educational force in the postmodern era. Camb. J. Educ. 2009, 39, 257-273. [CrossRef]

34. UNESCO. United Nations Decade of Education for Sustainable Development (DESD, 2005-2014). Review of Contexts and Structures for Education for Sustainable Development; UNESCO: Paris, France, 2009.

35. Rogers, E.M. Diffusion of Innovations, 4th ed.; The Free Press: New York, NY, USA, 1995.

36. United Nations. A/70/L.1. Transforming our world: The 2030 Agenda for Sustainable Development. In Proceedings of the Resolution Adopted by the General Assembly, Paris, France, 24 September 2015. Available online: http://www.un.org/en/development/desa/population/migration/generalassembly/docs/ globalcompact/A_RES_70_1_E.pdf (accessed on 10 March 2020).

37. Stephens, J.C.; Hernandez, M.E.; Román, M.; Graham, A.C.; Scholz, R.W. Higher education as a change agent for sustainability in different cultures and contexts. Int. J. Sustain. High. Educ. 2008, 9, 317-338. [CrossRef]

38. Mcmillin, J.; Dyball, R. Developing a whole-of-university approach to educating for sustainability. J. Educ. Sustain. Dev. 2009, 3, 55-64. [CrossRef]

39. Havea, P.H.; Mohanty, M. Professional development and sustainable development goals. In Quality Education. Encyclopedia of the UN Sustainable Development Goals; Leal Filho, W., Azul, A., Brandli, L., Özuyar, P., Wall, T., Eds.; Springer: Cham, Switzerland, 2020.

40. Činčera, J.; Kulich, J.; Gollová, D. Effectiveness, evaluation and support for environmental education programmes. Envigogika 2009, 4, 1-31.

41. Mader, C. Sustainability process assessment on transformative potentials: The Graz model for integrative development. J. Clean. Prod. 2013, 49, 54-63. [CrossRef]

42. Dlouhá, J.; Barton, A.; Janoušková, S.; Dlouhý, J. Social learning indicators in sustainability-oriented regional learning networks. J. Clean. Prod. 2013, 49, 64-73. [CrossRef]

43. Schulze, S. Evaluation of environmental education centres: A research design for the case study method. S. Afr. J. Environ. Educ. 1992, 12, 21-31.

44. Aipanjiguly, S.; Mochizuki, Y.; Fadeeva, Z. Emerging communities of practice: Regional centres of expertise discuss themes and evaluations. J. Educ. Sustain. Dev. 2008, 2, 17-20. [CrossRef]

45. Day, R.W.; Quinn, G.P. Comparisons of treatments after an analysis of variance in ecology. Ecol. Monogr. 1989, 59, 433-463. [CrossRef]

46. Sabir, M. The Role of Universities in Sustainable Development with Special Focus on Pakistan; University Malaysia Perlis (UNIMAP): Kangar, Malaysia, 2008; pp. 60-68.

47. Peer, V.; Stoeglehner, G. Universities as change agents for sustainability-Framing the role of knowledge transfer and generation in regional development processes. J. Clean. Prod. 2013, 44, 85-95. [CrossRef]

48. Cortese, A.D. The critical role of higher education in creating a sustainable future. Plan. High. Educ. 2003, 31, $15-22$. 
49. Reddy, C.; Schreuder, D. Environmental education scholarship in a 'marketised' setting: A case study in a university environmental education programme. Environ. Educ. Res. 2004, 10, 297-311. [CrossRef]

50. Shephard, K.; Furnari, M. Exploring what university teachers think about education for sustainability. Stud. High. Educ. 2013, 38, 1577-1590. [CrossRef]

51. Kanowski, P.; Yao, D.; Wyatt, S. SDG 4: Quality education and forests-'The golden thread'. In Sustainable Development Goals: Their Impacts on Forests and People; Katila, P., Ed.; Cambridge University Press: Cambridge, UK, 2020; pp. 108-145.

52. Jones, L.; Moore, R. Education, competence and the control of expertise. Br. J. Sociol. Educ. 1993, 14, $385-397$. [CrossRef]

53. Church, A.H. Do you see what I see? An exploration of congruence in ratings from multiple perspectives. J. Appl. Soc. Psychol. 1997, 27, 983-1020. [CrossRef]

54. Yammarino, F.J.; Atwater, L.E. Understanding self-perception accuracy: Implications for human resource management. Hum. Resour. Manag. 1993, 32, 231-247. [CrossRef]

55. Van der Heijden, B.I.J.M.; Nijhof, A.H.J. The value of subjectivity: Problems and prospects for 360-degree appraisal systems. Int. J. Hum. Resour. Manag. 2004, 15, 493-511. [CrossRef]

56. Lance, C.E.; Baxter, D.; Mahan, R.P. Multi-source performance measurement: A reconceptualization. In Performance Measurement: Current Perspectives and Future Challenges; Bennett, W., Lance, C.E., Woehr, D.J., Eds.; Erlbaum: Mahwah, NJ, USA, 2006; pp. 49-76.

57. Folkes, V.S. How consumers predict service quality: What do they expect? In The Service Quality Handbook; Scheuing, E.E.E., Christopher, W.F., Eds.; American Management Association: New York, NY, USA, 1993; pp. 108-123.

58. Hoffman, R.R.; Shadbolt, N.; Burton, A.M.; Klein, G.A. Eliciting knowledge from experts: A methodological analysis. Organ. Behav. Hum. Decis. Process. 1995, 62, 129-158. [CrossRef]

59. Hungerford, H. Environmental educators: A conversation with John Disinger. J. Environ. Educ. 2002, 33, 5-12. [CrossRef]

60. Mieg, H.A. The Social Psychology of Expertise: Case Studies in Research, Professional Domains, and Expert Roles; Lawrence Erlbaum Associates: Mahwah, NJ, USA, 2001.

61. Disinger, J.F.; Roth, C.E. Environmental Literacy; ERIC Digest 351201; Clearinghouse for Science, Mathematics, and Environmental Education: Columbus, OH, USA, 1992.

62. Van de Wiel, M.W.J.; Szegedi, K.H.P.; Weggeman, M.C.D.P. Professional learning: Deliberate attempts at developing expertise. In Professional Learning: Gaps and Transitions on the Way from Novice to Expert; Boshuizen, H.P.A., Bromme, R., Gruber, H., Eds.; Kluwer: Dordrecht, The Netherlands, 2004; pp. 181-206.

63. Vare, P.; Arro, G.; De Hamer, A.; Del Gobbo, G.; de Vries, G.; Farioli, F.; Kadji-Beltran, C.; Kangur, M.; Mayer, M.; Nijdam, C.; et al. Devising a competence-based training program for educators of sustainable development: Lessons learned. Sustainability 2019, 11, 1890. [CrossRef]

64. Lave, J.; Wenger, E. Communities of Practice: Learning, Meaning, and Identity; Cambridge University Press: Cambridge, UK, 1998.

65. Lee, D.H.L.; Shaari, I. Professional identity or best practices?-An exploration of the synergies between professional learning communities and communities of practices. Creat. Educ. 2012, 3, 457-460. [CrossRef]

66. Li, Y.; Krasny, M.E. Practice change in environmental education: Lessons from professional development. Environ. Educ. Res. 2019, 25, 1119-1136. [CrossRef]

67. Khelghat-Doost, H.; Sanusi, Z.A.; Tunku Fariddudin, T.F.F.D.; Jegatesen, G. Institutions of higher education and partnerships in education for sustainable development: Case study of the Regional Center of Expertise (RCE) Penang, Malaysia. J. Sustain. Dev. 2011, 4, 108-117. [CrossRef]

68. UNESCO; UNDP; UNPFA; UNHCR; UNICEF; UN Women. Incheon Declaration and Framework for Action for the Implementation of Sustainable Development Goal 4. 2016. Available online: http://uis.unesco.org/sites/default/files/documents/education-2030-incheon-framework-foractionimplementation-of-sdg4-2016-en_2.pdf (accessed on 10 March 2020).

69. Thomson, P. Uniting to Put Education at Heart of Sustainable Development. 2017. Available online: www.unesco.org/new/en/media-services/single-view/news/uniting_to_put_education_at_heart_ of_sustainable_development/ (accessed on 10 March 2020).

70. Rieckmann, M. Learning to transform the world: Key competencies in education for sustainable development. In Issues and Trends in Education for Sustainable Development; UNESCO: Paris, France, 2018; pp. 39-59. 
71. Kopnina, H. Teaching Sustainable Development Goals in the Netherlands: A critical approach. Environ. Educ. Res. 2017, 24, 1268-1283. [CrossRef]

72. Walter, A.I.; Helgenberger, S.; Wiek, A.; Roland, W. Measuring societal effects of transdisciplinary research projects: Design and application of an evaluation method. Eval. Program Plan. 2007, 30, 325-338. [CrossRef]

73. Brown, J.S.; Collins, A.; Duguid, P. Situated cognition and the culture of learning. Educ. Res. 1989, 18, 32-42. [CrossRef]

74. Lave, J.; Wenger, E. Situated Learning: Legitimate Peripheral Participation; Cambridge University Press: New York, NY, USA, 1991.

75. Brown, J.S.; Duguid, P. Organizational learning and communities-of-practice: Toward a unified view of working, learning, and innovation. Organ. Sci. 1991, 2, 40-57. [CrossRef]

76. Collins, A.; Brown, J.S.; Holum, A. Cognitive apprenticeship: Making thinking visible. Am. Educ. 1991, 15, 6-11.

77. Herrington, J.; Oliver, R. An instructional design framework for authentic learning environments. Educ. Technol. Res. Dev. 2000, 48, 23-48. [CrossRef]

78. Hesselink, F.; van Kempen, P.P.; Wals, A.E.J. ESDebate International Debate on Education for Sustainable Development; International Union for the Conservation of Nature: Gland, Switzerland, 2000.

79. Schnack, K. Participation, education and democracy: Implications for environmental education, health education, and education for sustainable development. In Participation and Learning: Developing Perspectives on Education and the Environment, Health and Sustainability; Reid, A., Nikel, J., Jensen, B.B., Simovska, V., Eds.; Springer: Dordrecht, The Netherlands, 2008; pp. 181-196.

80. Bardauskiene, D. The expert's estimates application in the preparation of city general plan. Technol. Econ. Dev. Econ. 2007, 13, 223-236. [CrossRef]

81. Kopar, C. The Characteristics of Effective Environmental Education Programs: An Exploration of the Perceptions of Environmental Educators in Southern Ontario. Master's Thesis, University of Waterloo, Waterloo, ON, Canada, 2013.

82. Zint, M.T.; Dowd, P.F.; Covitt, B.A. Enhancing environmental educators' evaluation competencies: Insights from an examination of the effectiveness of the My Environmental Education Evaluation Resource Assistant (MEERA) website. Environ. Educ. Res. 2011, 17, 471-497. [CrossRef]

83. Jickling, B.; Wals, A.E.J. Debating education for sustainable development 20 years after Rio: A conversation between Bob Jickling and Arjen Wals. J. Educ. Sustain. Dev. 2012, 6, 49-57. [CrossRef] 